\title{
Komposisi Mineral Cangkang Kerang Mutiara Pinctada margaritifera Di Sulawesi Utara
}

(Mineral composition of the pearl oyster shell Pinctada margaritifera In North Sulawesi)

\author{
Ockstan J. Kalesaran ${ }^{1}$, Cyska Lumenta ${ }^{2}$, Rizald Rompas ${ }^{2}$, Gybert Mamuaya ${ }^{2}$ \\ 1) Mahasiswa Program Doktor Ilmu Kelautan, FPIK Unsrat Manado \\ ${ }^{2)}$ Staf Pengajar Program Doktor Ilmu Kelautan, FPIK Unsrat Manado \\ Email: okstanju@yahoo.co.id
}

\begin{abstract}
This study aimed to analyze the chemical composition of the Pinctada margaritifera shells in North Sulawesi. Shells were collected from 3 (three) locations, namely: the coast of Arakan Minahasa Selatan waters, Bahoi Minahasa Utara waters and Talengen waters of Sangihe Islands, North Sulawesi. Three samples of shell powder each containing 100 grams, packed in a plastic bag to be analyzed using the ICP-OAS type Thermo scientific iCAP 6000 Series at the Wln (Water Laboratory Nusantara) Laboratory in Manado. The shell of P. margaritifera had macro mineral composition, namely calcium, phosphorus, magnesium, sodium and micro minerals, namely manganese and iron.
\end{abstract}

Keywords: Shells, Pinctada margaritifera, Mineral.

\section{PENDAHULUAN}

Indonesia merupakan negara
kepulauan yang luas keseluruhan wilayahnya dikelilingi oleh laut, memiliki potensi sumberdaya hayati laut yang berlimpah (megadiversitas). Program Pembangunan ekonomi dan kesejahteraan masyarakat Indonesia ke depan menempatkan laut sebagai sektor strategis penyumbang produktivitas nasional. Pembangunan berbasis kelautan dan sumberdaya maritim terus dioptimalkan dan menjadi basis pembangunan daya saing nasional (Anonim, 2014; Hanim dan Noorman, 2017). Kultivan kerang mutiara Pinctada margaritifera, merupakan salah satu potensi yang memerlukan pengelolaan dan perhatian yang terpadu. Aspek pengelolaan budidaya kerang ini diprioritaskan untuk menghasilkan produk mutiara yang bernilai jual tinggi. Selain itu pula, cangkang kerang tersebut dapat dimanfaatkan untuk beberapa produk bernilai ekonomis.

Menurut Onoda and Nakanishi (2012), Di Korea, sekitar 300.000 ton cangkang kerang dihasilkan setiap tahun dimana pemerintah Korea peduli pada kesehatan masyarakat dengan membiayai proyek untuk meningkatkan daur ulang limbah ini. Di Indonesia, tumpukan cangkang bivalve terlihat menggunung di kawasan Cilincing, Jakarta Utara. Limbah tersebut menimbulkan bau busuk dan 
pencemaran lingkungan (Detik news), namun di beberapa daerah tertentu memanfaatkan limbah cangkang sebagai kerajinan kulit kerang.

Pemanfaatan limbah cangkang sebagai sumber mineral telah banyak dilakukan antara lain; menurut Shah et al. (2014), kandungan tinggi kalsium karbonat dalam cangkang yang dapat digunakan dalam formulasi obat, dan konstruksi; John (2016), tepung cangkang Crassostrea madrasensis, secara efektif dapat digunakan dalam industri farmasi, pupuk, kapur, semen dan pakan ungags; Mahary (2017), memanfaatkan tepung kerang darah sebagai sumber kalsium pada paan ikan lele. Selanjutnya Yoa et al. (2014), melaporkan bahwa hasil analisis kimia cangkang kerang menunjukkan bahwa bioavailabilitas kalsium dari cangkang kerang lebih tinggi daripada garam kalsium yang digunakan dalam pengobatan allopathic dan unsur-unsur utama kalsium, magnesium, Ssodium yang sangat penting untuk kesehatan.

Sulawesi Utara memiliki potensi kekayaan sumberdaya laut khususnya di sektor perikanan. Limbah dari budidaya kerang mutiara khususnya cangkang kerang melimpah di beberapa lokasi budidaya dan perlu ditelaah pemanfaatannya sebagai suatu produk yang bernilai dan tidak merusak lingkungan. Penelitian ini bertujuan untuk mengetahui komposisi mineral cangkang kerang $P$. margaritifera di Sulawesi Utara.

\section{METODE PENELITIAN}

Sampel kerang $P$. margaritifera dikumpulkan dari 3 (tiga) lokasi di Sulawesi Utara yaitu pesisir perairan Arakan Minahasa Selatan, perairan Bahoi Minahasa Utara dan perairan Talengen
Kepulauan Sangihe Provinsi Sulawesi Utara. Pengambilan sampel cangkang kerang sebanyak 15 individu dari setiap wilayah, dilakukan pada bulan Januari sampai Mei 2018.

Cangkang kerang $P$. margaritifera dikumpulkan, disimpan di dalam kantong plastik dan diangkut ke laboratorium Kesehatan Ikan, Lingkungan dan Toksikologi Fakultas Perikanan dan Ilmu Kelautan Universitas Sam Ratulangi. Semua cangkang dibersihkan dari organisme yang menempel dan detritus, digosok dan dibersihkan dengan air untuk menghilangkan sisa bahan organik. Selanjutnya cangkang tersebut dikeringkan dibawah sinar matahari selama 1- 2 hari. Cangkang dipanaskan/dibakar selama 1-2 jam selanjutnya ditumbuk menjadi bubuk dengan menggunakan mortar. Proses selanjutnya yaitu penghalusan dengan penumbukkan dan disaring menjadi tepung.

Tiga sampel tepung cangkang masing-masing berisi $100 \mathrm{~g}$ bubuk dikemas dalam kantong plastik untuk dianalisis beberapa mineral seperti Calcium (Ca), Iron $(\mathrm{Fe})$, magnesium $(\mathrm{Mg})$, Mangan $(\mathrm{Mn})$, Natrium (Na) dan Phosfor (P). Sampel dibawa ke Laboratorium Wln (Water Laboratory Nusantara) Manado dan dianalisis menggunakan alat ICP-OAS tipe Thermo scientific iCAP 6000 Series.

\section{HASIL DAN PEMBAHASAN}

\section{Karakteristik cangkang kerang $P$. margaritifera}

Bentuk cangkang $P$. margaritifera berukuran besar, bulat secara garis besar, dengan katup kiri lebih cembung daripada katub kanan. Bagian luar berwarna hijau keabu-abuan dengan deretan sisik, dan bagian dalam pada permukaan nacre 
berwarna-warni keperakan, merah muda, merah atau hijau, sedangkan berwarna khas hitam pada margin prismatic (Gambar 1).

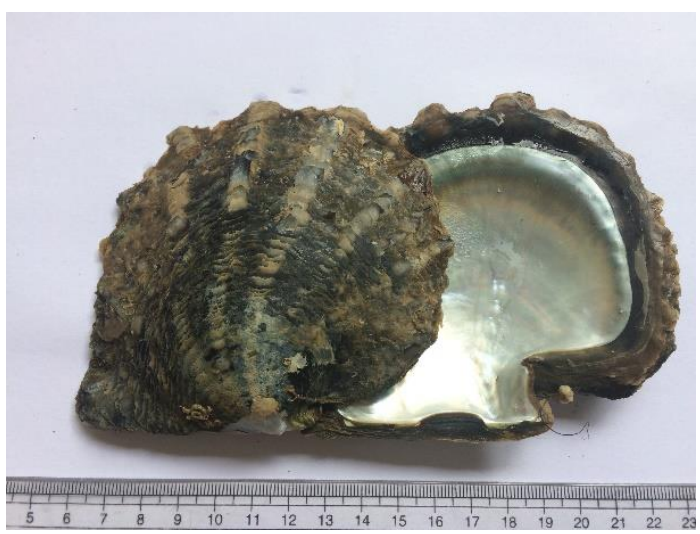

Gambar 1. Karakteristik cangkang kerang Pinctada margaritifera.

\section{Komposisi mineral}

Berdasarkan analisis laboratorium, cangkang kerang $P$. margaritifera memiliki komposisi mineral yang dapat dilihat pada Tabel 1.

Mineral merupakan salah satu komponen yang sangat dibutuhkan oleh semua makhluk hidup, dikenal sebagai zat anorganik atau kadar abu. Berdasarkan kegunaannya dalam aktivitas kehidupan, mineral dibagi menjadi dua golongan, yaitu mineral esensial dan nonesensial. Sedangkan berdasarkan banyaknya, mineral dibagi menjadi dua kelompok, yaitu mineral makro dan mineral mikro. Mineral makro diperlukan dalam jumlah relatif besar, meliputi $\mathrm{Ca}, \mathrm{P}, \mathrm{K}, \mathrm{Na}, \mathrm{Cl}, \mathrm{S}$, dan $\mathrm{Mg}$, sedangkan mineral mikro ialah mineral yang diperlukan dalam jumlah sangat sedikit, yaitu $\mathrm{Fe}, \mathrm{Mo}, \mathrm{Cu}, \mathrm{Zn}, \mathrm{Mn}$, Co, I, dan Se (Arifin, 2008; Wardhani, 2009).

Tabel 1 memperlihatkan komposisi kalsium lebih tinggi dari semua mineral yang di analisis untuk ketiga lokasi yang berbeda. Cangkang kerang dari pesisir perairan Talengen memiliki komposisi mineral kalsium (Ca) sebanyak 36.300 $\mathrm{mg} / \mathrm{kg}$.wet, diikuti perairan Bahoi $(31.600$ $\mathrm{mg} / \mathrm{kg}$.wet) dan perairan Arakan (25.400 $\mathrm{mg} / \mathrm{kg}$.wet). Ketiga sampel ini dari lokasi yang berbeda menunjukkan perbedaan komposisi mineral kalsium dari tiap tiap lokasi. Mineral kalsium merupakan mineral yang ditemukan dalam jumlah yang besar, hal ini disebabkan cangkang kerang disusun oleh sebagian besar calcium karbonat. Menurut Southgate \& Lucas (2008), cangkang terdiri dari sekitar $95 \%$ kalsium karbonat, yaitu sebagai kalsit dan aragonite, dimana merupakan bentuk biomineral yang tersusun dari kalsium karbonat ( $\mathrm{CaCO} 3)$, dan juga sejumlah kecil protein matriks organik.

Fosfor (P) adalah elemen penting untuk semua kehidupan, menjadi komponen struktural dan fungsional dari semua organisme. Fosfor merupakan komponen penting dari tulang, tulang rawan dan exoskeleton. Onoda and Nakanishi (2012) menjelaskan bahwa fosfor dalam cangkang kerang berupa kalsium fosfat. Kalsium fosfat adalah bahan penting untuk penukar ion, adsorben, dan sebagainya. Selanjutnya di jelaskan kebutuhan kalsium fosfat meningkat sekarang ini sebagai bahan daur ulang limbah dimana cangkang kerang telah digunakan sebagai bahan baku untuk berbagai peruntukan.

Di alam, mineral magnesium ditemukan di tanah, bebatuan, air, air laut, dan pada zat hijau daun (klorofil). AbdelAal (2017) menjelaskan bahwa magnesium $(\mathrm{Mg})$ ada di air laut sebagai ion magnesium, dan komponen utama air laut. Pada air laut, magnesium terionisasi menjadi kation $\mathrm{Mg} 2+$, membentuk senyawa kristal magnesium klorida $\left(\mathrm{MgCl}_{2}\right)$. 
Tabel 1. Komposisi mineral cangkang kerang $P$. margaritifera

\begin{tabular}{|c|c|c|c|c|c|c|}
\hline \multirow[t]{2}{*}{ No } & \multirow[t]{2}{*}{ Mineral } & \multicolumn{3}{|c|}{$\begin{array}{l}\text { Tepung cangkang Kerang } \\
\text { P. margaritifera }\end{array}$} & \multirow[t]{2}{*}{ Rata-rata } & \multirow[t]{2}{*}{ Ket. } \\
\hline & & $\begin{array}{l}\text { Perairan } \\
\text { Arakan }\end{array}$ & $\begin{array}{l}\text { Perairan } \\
\text { Bahoi }\end{array}$ & $\begin{array}{l}\text { Perairan } \\
\text { Talengen }\end{array}$ & & \\
\hline & Mineral makro & & & & & \\
\hline 1 & Kalsium $(\mathrm{Ca})$ & 25400 & 31600 & 36300 & 31100 & $\mathrm{mg} / \mathrm{kg}$.wet \\
\hline 2 & Magnesium $(\mathrm{Mg})$ & 7 & 6 & 6 & 6,33 & $\mathrm{mg} / \mathrm{kg}$.wet \\
\hline 3 & Sodium $(\mathrm{Na})$ & 5 & 5 & 5 & 5,00 & $\mathrm{mg} / \mathrm{kg}$.wet \\
\hline \multirow[t]{2}{*}{4} & Phospor (P) & 50 & 50 & 50 & 50,00 & $\mathrm{mg} / \mathrm{kg}$.wet \\
\hline & Mineral mikro & & & & & \\
\hline 5 & Besi (Fe) & 3 & 3 & 3 & 3,00 & mg/kg.wet \\
\hline 6 & Mangan (Mn) & 23,9 & 30,3 & 40,6 & 31,60 & $\mathrm{mg} / \mathrm{kg}$.wet \\
\hline
\end{tabular}

Natrium sebagian besar terdapat dalam plasma darah dan cairan di luar sel (ekstraseluler), beberapa diantaranya juga terdapat dalam tulang. Yaswir dan Ferawati (2012); Khoerunnisa (2017), natrium merupakan elektrolit dimana senyawa di dalam larutan yang berdisosiasi menjadi partikel yang bermuatan (ion) positif atau negatif. Sebagian besar proses metabolisme memerlukan dan dipengaruhi oleh elektrolit.

Komposisi mineral mikro yang terdapat dalam cangkang kerang $P$. margaritifera antara lain Fe dan Mn. Kadar mangan pada tepung cangkang kerang menunjukkan perbedaan di ketiga lokasi perairan. Cangkang yang berasal perairan Talengen memiliki kadar mangan 40.6 $\mathrm{mg} / \mathrm{kg}$.wet diikuti daerah Bahoi (30.3 $\mathrm{mg} / \mathrm{kg}$ ) dan Arakan (23.9 mg/kg). Kadar mineral mangan (Mn) pada tepung cangkang ini lebih tinggi dibandingkan kadar besi (Fe). Kandungan Fe ditemukan sama pada lokasi yang berbeda.

Mineral mikro merupakan mineral yang terdapat dalam jumlah kecil dalam tubuh yaitu besi $(\mathrm{Fe})$, mangan $(\mathrm{Mn})$, iodine (I), Copper $(\mathrm{Cu})$, dan Selenium (Se). Mineral mangan tersebar secara luas dalam banyak bentuk; oksida, silikat, karbonat adalah senyawa yang paling umum. Mangan berada pada bentuk manganous $(\mathrm{Mn} 2+)$ dan manganik (Mn 4+). Pada perairan dengan kondisi anaerob akibat dekomposisi bahan organik dengan kadar yang tinggi, Mn 4+ pada senyawa mangan dioksida mengalami reduksi menjadi $\mathrm{Mn}$ $2+$ yang bersifat larut. Mn2+ berikatan dengan nitrat, sulfat, dan klorida, dan larut dalam air. Mn dan Fe saling erat berkaitan dalam proses fotosintesis pada alga.

Berdasarkan data diatas dapat diasumsikan, perbedaan kandungan mineral disebabkan oleh perbedaan kesuburan perairan, sehingga mempengaruhi penyerapan makanan oleh organismepun berbeda. Selain ini pula, produktivitas suatu perairan berbeda dengan perairan lainnya karena sangat ditentukan oleh sifat fisika dan kimia serta organisme hidup pendukung lainnya. Hal ini perkuat oleh Rahayu $d k k$. (2015) bahwa perbedaan kandungan mineral pada organisme perairan umumnya dipengaruhi oleh daya absorpsi makanan dari berbagai zat yang tersuspensi dalam perairan tempat tinggalnya. Kemampuan organisme untuk mengabsorpsi berbagai zat tersuspensi ini 
dipengaruhi oleh beberapa faktor yaitu kondisi lingkungan, ukuran organisme, spesies, pH dan kondisi kelaparan dari organisme.

Cangkang kerang ini ketersediaan melimpah, pemanfaatannya belum dilakukan bahkan umumnya dianggap sebagai limbah dan dibiarkan begitu saja oleh nelayan. Ketidaktahuan masyarakat pesisir pantai dapat menimbulkan masalah lingkungan dan mengakibatkan pemborosan sumber daya alam. Dilihat dari potensi sumber mineral kalsium, natrium, fosfor, magnesium, mangan, dan besi yang terkandung dalam tepung cangkang, maka perlu dilakukan pemanfaatan limbah secara optimal sehingga menjadi produk perikanan yang bernilai jual tinggi.

\section{KESIMPULAN}

Cangkang kerang P. margaritifera memiliki komposisi mineral makro yaitu kalsium, fosfor, magnesium, natrium dan mineral mikro yaitu mangan dan besi. Perbedaan komposisi mineral disebabkan oleh perbedaan kesuburan perairan, sehingga mempengaruhi penyerapan makanan oleh organismepun berbeda. Selain ini pula, ditentukan oleh organisme pendukung dan faktor fisika kimia perairan.

\section{DAFTAR PUSTAKA}

Abdel-Aal H., Cohdy K., Abdelkreem. 2017. Seawater bittern a precursor for magnesium chloride separation: Discussion and assessment of case studies. International Journal of waste resources. Volume 7, issue 1.

Anonim. 2014. Kajian strategi Pengelolaan perikanan berkelanjutan.

Kementerian PPN/Bappenas
Direktorat Kelautan dan Perikanan. 120hal.

Arifin Z. 2008. Beberapa unsur mineral esensial mikro dalam system biologi dan metode analisisnya. Jurnal Litbang Pertanian. 27(3): 99-105.

Hanim L., Noorman MS. 2017. Kebijakan kelautan dalam rangka menjaga dan mengelola sumber daya alam laut sebagai upaya mewujudkan Indonesia sebagai poros maritime dunia. Legalitas, Vol 25, No. 1; 1-12.

John AT. 2016. Chemical Composition of the Edible Oyster Shell Crassostrea madrasensis (Preston 1916). Journal of Marine Biology and Aquaculture.

Khoerunnisa. 2017. Isolasi dan karakterisasi nano kalsium dari cangkang kijing local (Pilsbryoconcha exilis) dengan metode presipitasi. Skripsi. IPB Bogor.

Mahary A. 2017. Pemanfaatan tepung cangkang kerang darah (Anadara granosa) sebagai sumber kalsium pada pakan ikan lele (Clarias batrachus sp). Acta Aquatica, 4(2): 63-67.

Onoda H., Nakanishi H. 2012. Preparation of Calcium Phosphate with Oyster Shells. Natural Resources, 3: 71-74.

Rahayu R., Leksoni T., Desmelati. 2015. Analisis Kandungan Mineral pada Tepung Cangkang Kerang Air Tawar (Pilsbryoconcha exilis) Berdasarkan Ukuran Cangkang yang Berbeda. download.portalgaruda.org/article.ph p? article $=335664 \& v a l=6450 \&$ titl

Shah RA., Prabhakar MN., Lee WD., Kim BS., Song JI. 2014. Development and Characterization of Oyster Shell Powder Filled Polypropylene Composite. Composites Research, Vol. 27, No. 5, 201-206. 
Southgate PC., Lucas J.S. 2008. The pearl oyster. Elservier, The Boulevard longford Lane Kidlington, Oxford Uk. 565p.

Wardhani Y.K. 2009. Karakteristik fisik dan kimia tepung cangkang kijing lokal (Pilsbryoconcha exilis). Skripsi Fakultas Perikanan dan Ilmu Kelautan IPB.
Yaswir R., Ferawati I. 2012. Fisiologi dan Gangguan Keseimbangan Natrium, Kalium dan Klorida serta Pemeriksaan Laboratorium. Jurnal Kesehatan Andalas 1(2):80-85.

Yoa Z., Xia M., Li H., Chen T., Ye Y., Zheng H. 2014. Bivalve Shell: Not an Abundant Useless Waste but a Functional and Versatile Biomaterial. Critical Reviews in Environmental Science and Technology, 44: pp2502-2530. 